\title{
SUANITE, A NEW MAGNESIUM BORATE MINERAL FROM HOL KOL, SUAN, NORTH KOREA
}

\author{
TAKEO WATANABE \\ Geological Institute, University of Tokyo.
}

\begin{abstract}
A new mineral from the Hol Kol mine, North Korea of the composition $\mathrm{Mg}_{2} \mathrm{~B}_{2} \mathrm{O}_{5}$, named suanite, has been described. The mineral is found usually as fibrous aggregates associated with kotoite and other borate minerals in marble which borders the gold- and copper-bearing diopside-clinohumite skarn mass. The crystal usually elongated parallel to [010] is monoclinic with the following dimen. sions: $a=12.10 \AA ., b=3.12 \AA$., $c=9.36 \AA$., $\beta=104^{\circ} 20^{\prime}$ (Weissenberg photographs, $\operatorname{CuK} \alpha\rangle=1.54 \AA$.). The space group $\mathrm{C}_{4 \mathrm{~h}}^{5}-\mathrm{P} 21 / \mathrm{a}$. The unit cell contains $4\left[\mathrm{Mg}_{2} \mathrm{~B}_{2} \mathrm{O}_{5}\right]$. Colourless. Hardness 51. Sp. gr. 2.91. Opt. properties : $\alpha=1.596, \beta=1.639, \gamma=1.670$ $\gamma \alpha=0.074,2 \mathrm{~V}=70^{\circ}$ (negative); $\mathrm{r}>\mathrm{v}$, weak; $\mathrm{X} / \mathrm{b}$. The chemical analysis by $\mathrm{N}$. Saito and $\mathrm{N}$. Kokubu follows; $\mathrm{SiO}_{2} 0.60, \mathrm{Al}_{2} \mathrm{O}_{3}+\mathrm{Fe}_{2} \mathrm{O}_{3} 0.95, \mathrm{MgO} 46.63, \mathrm{CaO} 5.06$, $\mathrm{B}_{2} \mathrm{O}_{3} 40.08, \mathrm{CO}_{2} 5.01, \mathrm{H}_{2} \mathrm{O}(+) 0.90, \mathrm{H}_{2} \mathrm{O}(-) 0.23$, total $99.46 \%$. After deduction of $\mathrm{CaCO}_{3}$ and other impurities, $\mathrm{MgO} 53.7, \mathrm{~B}_{2} \mathrm{O}_{3} 46.3 \%$ against the theoretical composition $\mathrm{MgO} 53.66, \mathrm{~B}_{2} \mathrm{O}_{3} 46.34 \%$. The mineral is not easily affected by cold $\mathrm{HCl}$. The X-ray powder diagram of the mineral is very similar to but definitely different from, that of the artificial $\mathrm{Mg}_{2} \mathrm{~B}_{2} \mathrm{O}_{5}$, to which it is converted when heated up to $1,000^{\circ} \mathrm{C}$..
\end{abstract}

\section{Introduction}

In 1939 during the course of a study of the gold- and copperbearing skarn minerals from the Hol Kol mine the writer found among other borate minerals a mineral, possibly a borate too, which could not be identified with any known one. However, the material available for investigation was so scarce that only its optical properties could be determined with certainty under the microscope. By 1943 after a revisit by the writer of the district material enough for further study had been accumulated and a chemical analysis 
was executed. It turned out to be a magnesium pyroborate roughly of the composition $2 \mathrm{MgO} \cdot \mathrm{B}_{2} \mathrm{O}_{3}$. A brief account was then given, tentatively giving it a new mineral name, suanite.13)

An X-ray study by Takeuchir) which was made and published prior to the completion of our study has revealed that the crystal structure of the mineral is composed of the pyroborate molecular groups, $\mathrm{B}_{2} \mathrm{O}_{5}$.

The writer gives below a detailed mineralogical description of the mineral.

\section{Occurrence and paragenesis}

The Hol Kol* gold copper mine is located in the Suan gold mining district ${ }^{12)}$, Suan County, Hwanghae-do, ${ }^{* *}$ about 75 kilometers eastsouth-east of the city of Pyongyang, ${ }^{* * *}$ the capital of North Korea. We found in the marble that predominates in the district such boron-bearing minerals as ludwigite and warwickite as well as kotoite, a new mineral also first described by the writer(10)11). Acicular or prismatic crystals of suanite in radiated masses and in subparallel intergrowths are embedded in the kotoite-marble and are usually associated with beside borate minerals clinohumite, spinel and calcite. The intimate association of suanite with other magnesium-bearing borates having similar crystal structures ${ }^{2 / 5) 6 / 8)}$ is remarkable. The occurrence of warwickite will be described in a separate paper. A secondary borate mineral, probably szaibelyite, is also found along cracks of suanite.

\section{Physical and optical properties}

Suanite is white in colour and translucent and perfectly colourless in thin section. Its luster is silky to pearly. Its hardness is 5.5 and its specific gravity measured is 2.91 (suspension method). Difficult to fuse.

Suanite is optically biaxial and negative. Its fibers are parallel 
to $\mathrm{b}$ and $\mathrm{X}$. Indices of refraction were determined by immersion method;

$\alpha=1.596, \beta=1.639, \gamma=1.670, \gamma-\alpha=0.074$ and $2 V_{a}=70^{\circ}$. Dispersion is $\mathrm{r}>\mathrm{v}$, weak. (Table 1 )

Crystallographic characters of suanite cannot easily be determined as its fibers are usually too slender. Under the microscope the slender crystals nearly cut parallel to (010), that is to say, being nearly perpendicular to $b$-axis show monoclinic crystal outlines as shown in Fig. 1 (Plate I). Facial angles were measured under the microscope after rendering by means of a universal stage the parallel [010] edges, along which the crystals are usually elongated, vertical. The outlines of the crystal and their relation to the optical orientations are shown in Fig. 3.

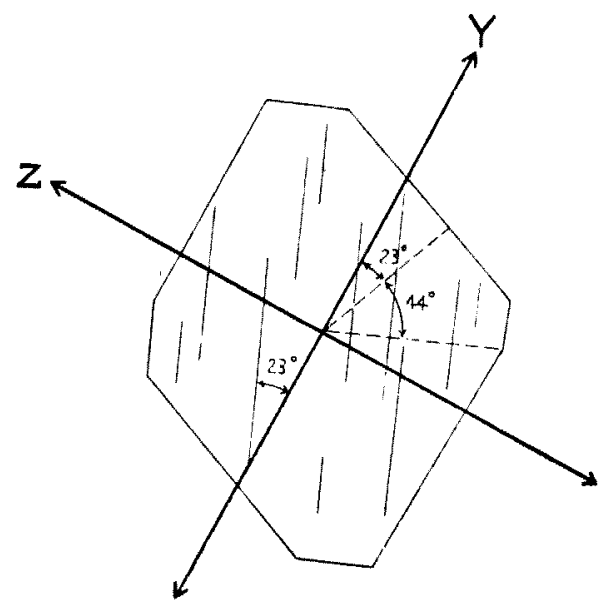

Fig. 3. The outlines of a crystal of suanite cut perpendicular to b-axis and their relation to the optical orientations.

The slender crystals of suanite separated from the fibrous aggregates were studied with rotation and Weissenber 3 photographs by Y. Takeuchi and its crystal structure has already been determined 
by $h^{7}{ }^{7}$ in 1952 . The result of his structural studies is as follows : the unit cell has the dimensions $a_{0}=12.10 \pm 0.05 \AA$., $b_{0}=3.12 \pm 0.02 \AA$., $c_{0}=9.36 \pm 0.05 \AA ., a_{0}: b_{0}: c_{0}=3.880: 1: 3.000, \beta=104^{\circ} 20^{\prime} \pm 30^{\prime}$, and contains four molecules of $\mathrm{Mg}_{2} \mathrm{~B}_{2} \mathrm{O}_{5}$. Its space group is $\mathrm{C}_{2 h}^{5}-\mathrm{P}_{2} / \mathrm{a}$. Calculated specific gravity is 2.89 against 2.91 measured.

Table 1. Comparison of some properties of kotoite, suanite, artificial pyroborate, and szaibelyite.

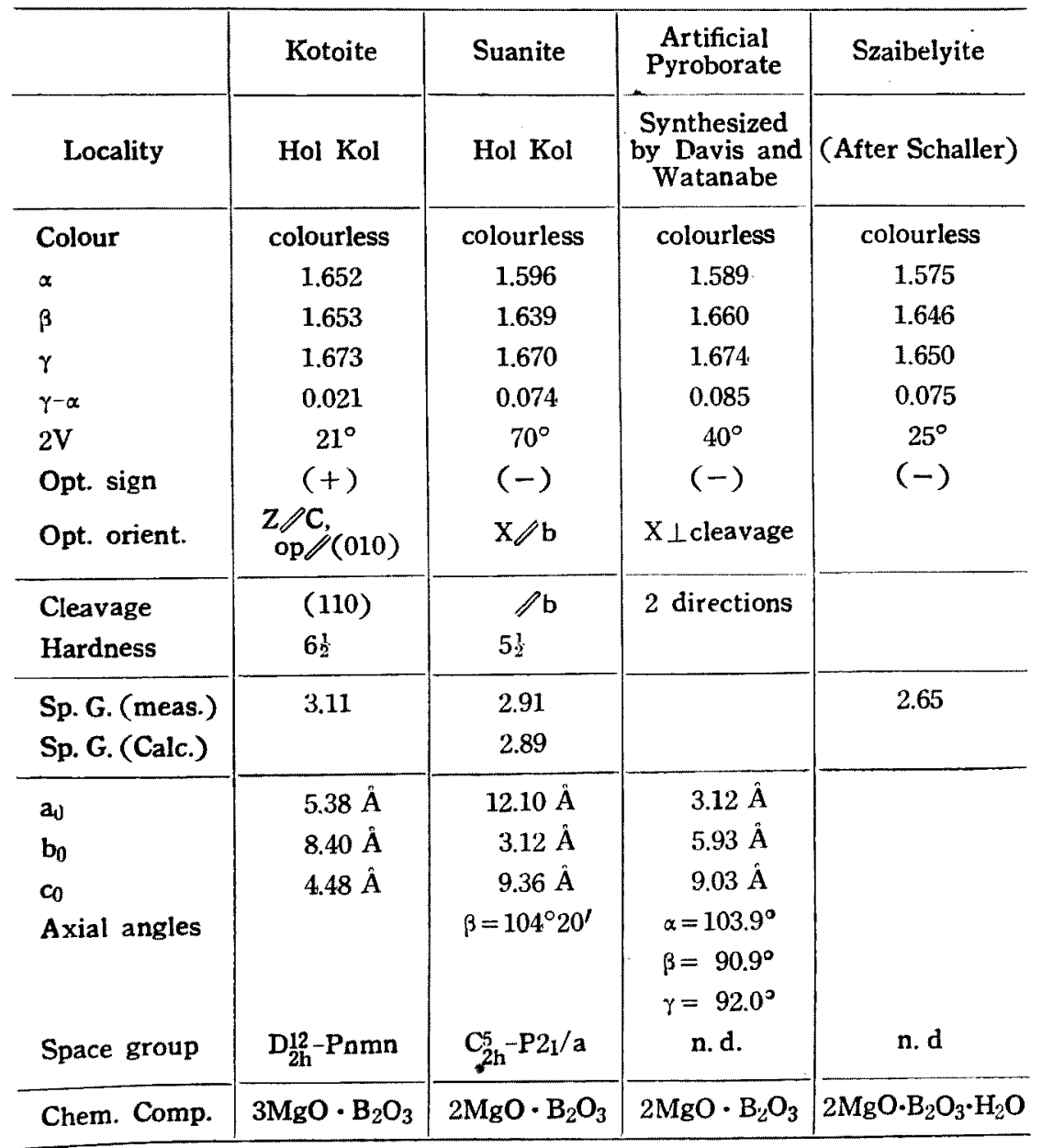




\section{Chemical composition}

It was very difficult to isolate pure materials for analysis due to the close association of suanite with clinohumite, szaibelyite and calcite. When the finely powdered suanite is treated by hydrochloric acid it is gelatinized, although the mineral is somewhat difficultly soluble in the cold and dilute acid.

Carefully separated fibrous mass of the mineral was first analyzed by $\mathrm{K}$. Isono in the laboratory of the Geological Survey of Japan, by the courtesy of Dr. S. Yamane, then Director of the Survey. Treatment of the sample with $\mathrm{HCl}$ showed effervescence of $\mathrm{CO}_{2}$. The result of the analysis is given in Table 2 , No. 1 .

Table 2. Chemical analyses of suanite

\begin{tabular}{|c|c|c|c|c|c|c|c|}
\hline & 1 & 2 & $2 a$ & $2 b$ & 3 & 4 & 5 \\
\hline & $\%$ & $\%$ & & & $\%$ & $\%$ & $\%$ \\
\hline $\mathrm{SiO}_{2}$ & 0.70 & 0.60 & 0.0100 & & 0.80 & & \\
\hline $\mathrm{Al}_{2} \mathrm{O}_{3}$ & 0.97 & & & & & & \\
\hline $\mathrm{Fe}_{2} \mathrm{O}_{3}$ & 0.33 & 0.95 & 0.0095 & & 0.63 & & \\
\hline $\mathrm{MgO}$ & 46.48 & 46.63 & 1.1565 & 1.1270 & 50.64 & 53.66 & 47.91 \\
\hline $\mathrm{CaO}$ & 3.70 & 5.06 & 0.0902 & & 1.52 & & \\
\hline $\mathrm{Na}_{2} \mathrm{O}$ & 0.90 & $\longrightarrow$ & - & & & & \\
\hline $\mathrm{K}_{2} \mathrm{O}$ & 0.00 & - & $\longrightarrow$ & & & & \\
\hline $\mathrm{B}_{2} \mathrm{O}_{3}$ & 38.20 & 40.08 & 0.5756 & 0.5756 & 42.28 & 46.34 & 41.38 \\
\hline $\mathrm{CO}_{2}$ & 5.70 & 5.01 & 0.1139 & & & & \\
\hline $\begin{array}{l}\mathrm{H}_{2} \mathrm{O}(+) \\
\mathrm{H}_{2} \mathrm{O}(-)\end{array}$ & 3.50 & $\begin{array}{l}0.90 \\
0.23\end{array}$ & $\begin{array}{l}0.0500 \\
0.0128\end{array}$ & & $\begin{array}{l}3.87 \\
0.19\end{array}$ & & 10.71 \\
\hline Total & 100.48 & 99.46 & & & 99.93 & 100.00 & 100.00 \\
\hline
\end{tabular}

1. Suanite containing a small amount of calcite. Analyst K. Isono, Geol. Surv. of Japan (1942).

2. Suanite containing a small amount of calcite. Analysts N. Saito and N. Kokubu (1948).

2a. Molecular ratios.

2b. Less $\mathrm{Mg}_{2} \mathrm{SiO}_{4}, \mathrm{Mg}(\mathrm{Al}, \mathrm{Fe})_{2} \mathrm{O}_{4}$ and $\mathrm{CaCO}_{3}$.

3. Suanite containing szaibelyite. Analysts N. Saito and Kokubu (1949).

4. Calculated composition of suanite, $2 \mathrm{MgO} \cdot \mathrm{B}_{2} \mathrm{O}_{3}$.

5. Calculated composition of szaibelyite, $2 \mathrm{MgO} \cdot \mathrm{B}_{2} \mathrm{O}_{3} \cdot \mathrm{H}_{2} \mathrm{O}$. 
In order to know the nature of water found in the analysis No. 1, the materials separated from other samples were analyzed by N. Saito and N. Kokubu at the Kyushu University in 1949. A small amount of calcite was still contained in the analyzed materials. The analytical results were also given in Table 2, Nos. 2 and 3.

After reducing $\mathrm{CaCO}_{3}, \mathrm{Mg}_{2} \mathrm{SiO}_{4}$ and $\mathrm{Mg}(\mathrm{Al}, \mathrm{Fe})_{2} \mathrm{O}_{4}$ as impurities, the analysis in column 2 gives molecular ratio $[\mathrm{MgO}]:\left[\mathrm{B}_{2} \mathrm{O}_{3}\right]=1.96$ : 1.00 , which agrees well with the formula $2 \mathrm{MgO} \cdot \mathrm{B}_{2} \mathrm{O}_{3}$ or $\mathrm{Mg}_{2} \mathrm{~B}_{2} \mathrm{O}_{5}$.

Higher values for $\mathrm{H}_{2} \mathrm{O}$ in column 1 and 3 attributable to the presence of secondary szaibelyite in suanite aggregates.

\section{Thermal study of suanite}

The differential thermal analysis has been carried out on pulverized specimens of suanite (Fig. 4C). The curve shows an endothermic peak at $630^{\circ} \mathrm{C}$. $\mathrm{X}$-ray powder patterns obtained from the suanite heated to $1000^{\circ} \mathrm{C}$. and artificial $\mathrm{Mg}_{2} \mathrm{~B}_{2} \mathrm{O}_{5}$ by means of Phillips X-ray spectrometer show that both materials are identical in structure. It may therefore be assumed that at $630^{\circ} \mathrm{C}$. the natural monoclinic suanite is transformed into triclinic $\mathrm{Mg}_{2} \mathrm{~B}_{2} \mathrm{O}_{5}$. On the other hand, Takeuchi, from his X-ray study has concluded that magnesium pyroborate $\mathrm{Mg}_{2} \mathrm{~B}_{2} \mathrm{O}_{5}$ is dimorphous.

As an appreciable amount of water had been always reported as the results of chemical analysis of suanite the nature of the water was studied by heating its pulverized sample on a thermobalance at Tokyo Institute of Technology up to $900^{\circ} \mathrm{C}$. (Fig. 4A). The thermal curves show that only a loss in weight takes place gradually up to $700^{\circ} \mathrm{C}$.. However, this increases rather abruptly between $700^{\circ} \sim 900^{\circ} \mathrm{C}$.. This is probably due to the presence of small amounts of szaibelyite $\left(2 \mathrm{MgO} \cdot \mathrm{B}_{2} \mathrm{O}_{3} \cdot \mathrm{H}_{2} \mathrm{O}\right)$ and calcite in the sample. It is to note that the dehydration temperature of szaibelyite is about $670^{\circ} \mathrm{C}$. and the dissociation temperature of calcite is $880^{\circ} \mathrm{C}$.. 


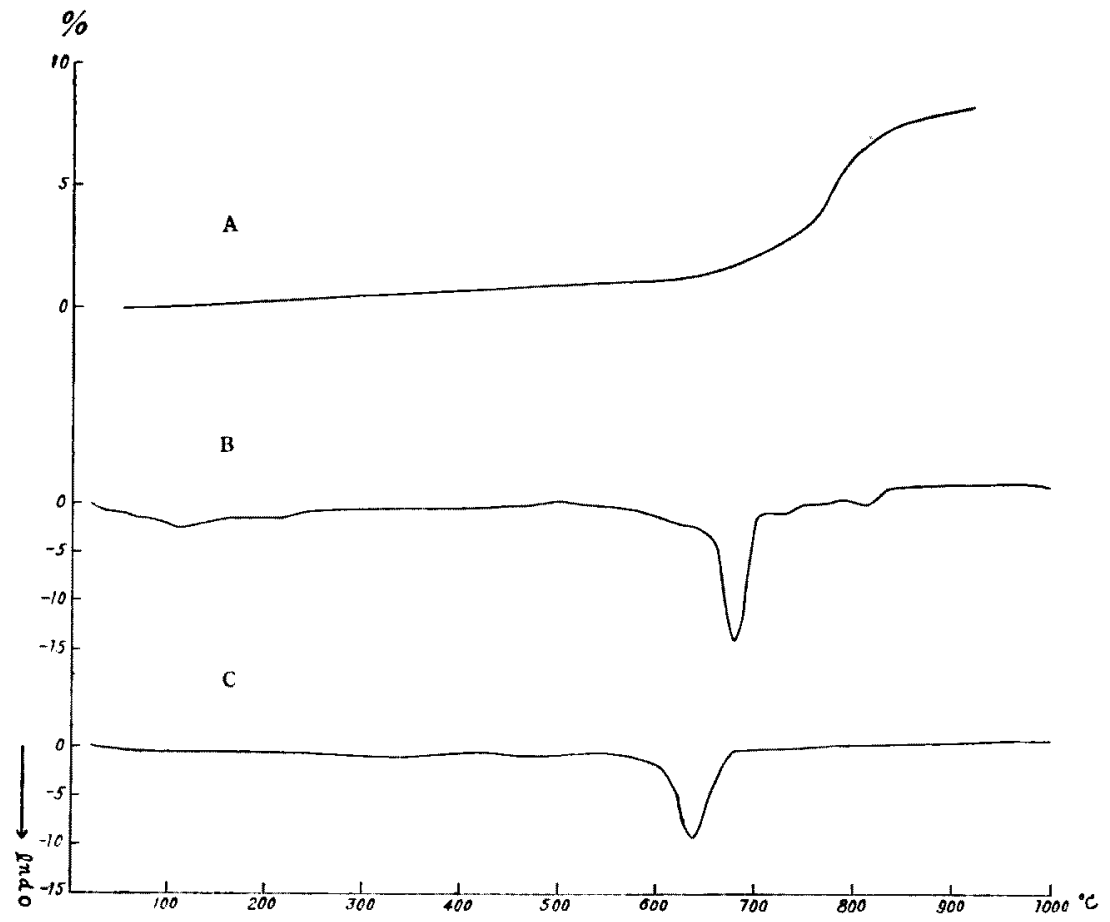

Fig. 4. A) Dehydration curve of the sample consisting mainly of suanite with small amounts of calcite and szaibelyite.

B) Differential thermal analysis curve of szaibelyite from Rézbánya. An endothermic peak at $670^{\circ} \mathrm{C}$. is very marked.

C) Differential thermal analysis curve of nearly pure suanite which shows a small endothermic peak at $630^{\circ} \mathrm{C}$. probably due to the inversion of natural monoclinic suanite to triclinic magnesium pyroborate.

\section{Synthesis}

The first synthesis of $\mathrm{Mg}_{2} \mathrm{~B}_{2} \mathrm{O}_{5}$ has been reported by W. Guertler ${ }^{3}$ ) in 1904. Later N. A. Toporov and P. F. Konovalov' and also H. M. Davis and M. A. Knight, ${ }^{1)}$ who studied the binary system $\mathrm{MgO}-\mathrm{B}_{2} \mathrm{O}_{3}$, could obtain three binary compounds of magnesium-oxide and boric acid: $\mathrm{MgO} \cdot \mathrm{B}_{2} \mathrm{O}_{3}$ (metaborate), $2 \mathrm{MgO} \cdot \mathrm{B}_{2} \mathrm{O}_{3}$ (pyroborate) and $3 \mathrm{MgO} \cdot \mathrm{B}_{2} \mathrm{O}_{3}$ (kotoite, orthoborate). Synthesized crystals of the magnesium pyroborate was studied optically by Davis and Knight. 
The magnesium pyroborate was synthesized also by the writer by cooling slowly fused mass of $\mathrm{MgO}$ and $\mathrm{B}_{2} \mathrm{O}_{3}$ in the proportion $1: 1$. The product was studied with $\mathrm{X}$-ray by $\mathrm{Y}$. Takeuchi. His result shows that the artificial $\mathrm{Mg}_{2} \mathrm{~B}_{2} \mathrm{O}_{5}$ is triclinic having nearly the same structure with $\mathrm{Co}_{2} \mathrm{~B}_{2} \mathrm{O}_{5}$. Although no artificial monoclinic $\mathrm{Mg}_{2} \mathrm{~B}_{2} \mathrm{O}_{5}$ has yet been reported till now, as stated before, the natural suanite crystals when heated to $1000^{\circ} \mathrm{C}$. are reduced into fine aggregates that show the same powder-pattern as the artificial pyroborate.

\section{Acknowledgements}

The writer wishes to express his sincere thanks to Professor $T$. Ito of the University of Tokyo and Professor H. M. Davis for their helpful suggestions and aids during the course of the present investig. ation and to Prof. Dr. Keith of the Pennsylvania State College, Dr. Y. Takeuchi and Mr. S. Takasu of the University of Tokyo for their assistances in X-ray studies. Further acknowledgements also are made to Dr. S. Yamane, Dr. N. Saito and Mr. N. Kokubu for their kindness in chemical analyses of minerals, and to Prof. T. Sudo and Mr. M. Kimura of the University of Tokyo, Mr. H. Yamada and Mr. S. Iwai of the Tokyo Institute of Technology for their kindness in thermal studies on suanite.

\section{REFERENCES}

1) Davis, H. M. and M. A. Knight: Jour. Amer. Cer. Soc., 28, 4, 97-102 (1945).

2) Geijer, Per : Geol. Fören. Förh., 61, 1, 19-33 (1939).

3) Guertler, W.: Zeit. anorg. allg. Chemie., 40, 225-253 (1904).

4) Sadanaga, R.: X-ray, 5, 1-2, 2-7 (1948).

5) Schaller, W. T.: Amer. Mineral., 27, 7, 467-486 (1942).

6) Takeuchi, Y., T. Watanabe and T. Ito: Acta Cryst., 3, 98-107 (1950).

7) Takeuchi, Y.: Acta Cryst., 5, 574-581 (1952).

8) Tilley, C.E.: Min. Mag., 29, 214, 621-666 (1951).

9) Toporov, N.A. and P.F. Konovalov: Zhur. Fiz. Khim. (U.S.S. R.) 14, 1103-1109 (1940); Chem. Abs. 35, 3886.

10) Watanabe, T.: Min. u. Petr. Mitt., 50, 441-463 (1939). 
62 Suanite, a new magnesium borate mineral from Hol Kol

11) Watanabe, T.: Fortschr. Min. Krist. u. Petr., 32, 10-11 (1939).

12) Watanabe, T.: Jour. Fac. Sci. Hokkaido Univ., Ser. 4, 6 (3-4), 205-303 (1943).

13) Watanabe, T.: The geology and mineral resources of Far East, K-VII-102, 1-18 (1952). 


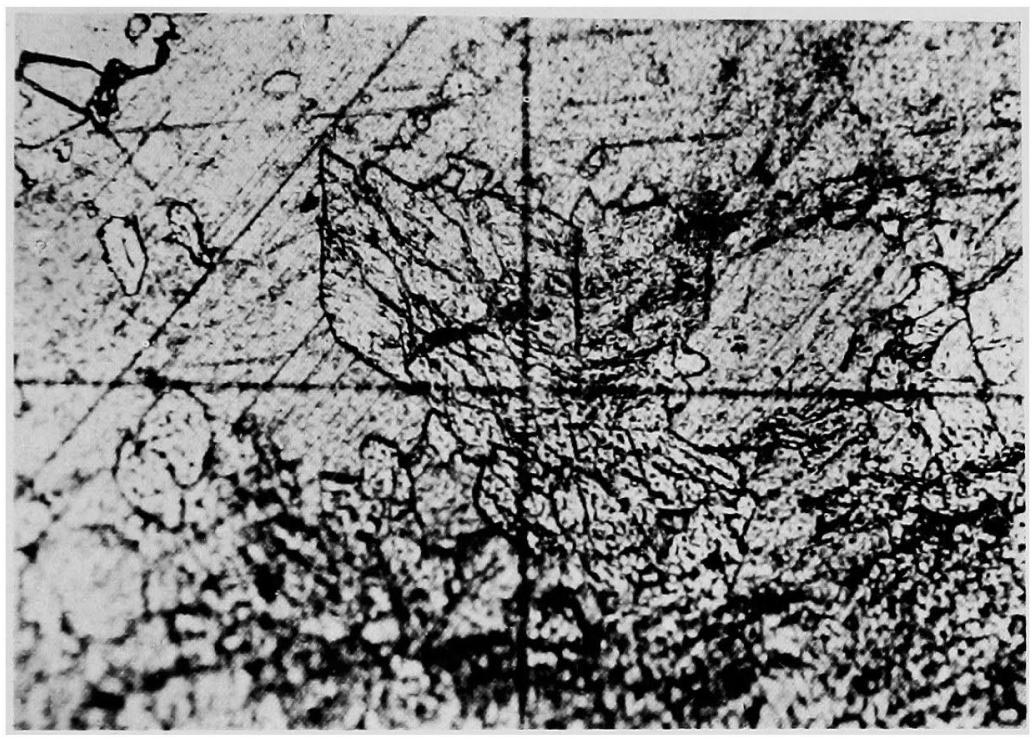

Fig. 1. Suanite $\perp b \times 63$.

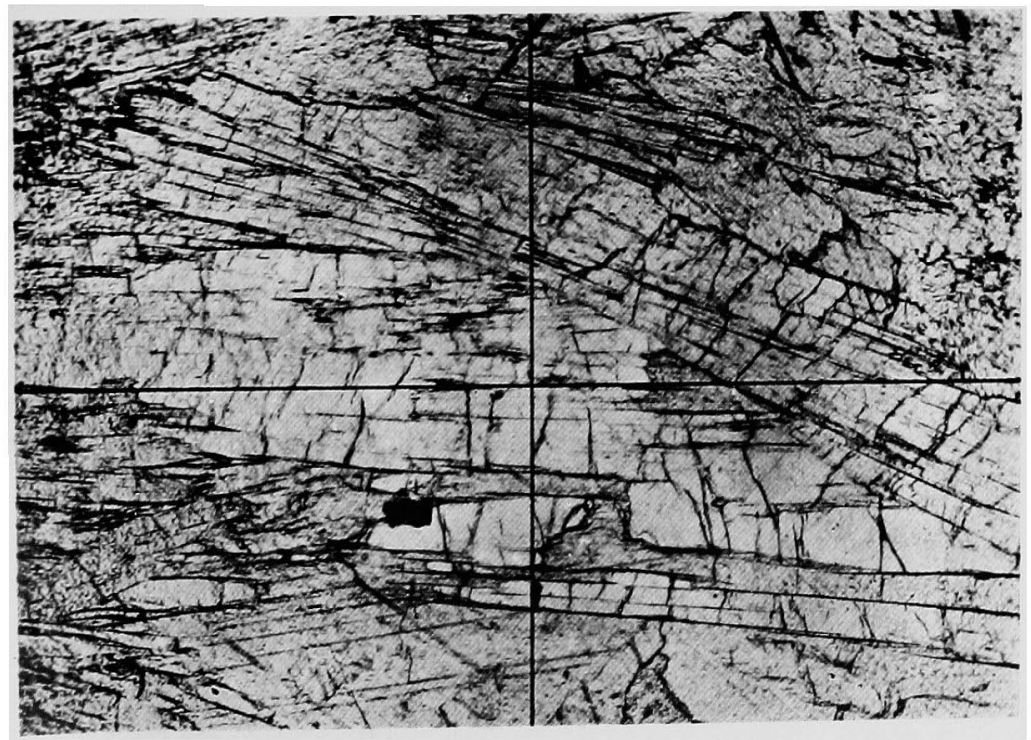

Fig. 2. Suanite $/ / \mathrm{b} \times 50$. 